\title{
Malaysian English Language Teachers' Agency in Using Digital Technologies During the Pandemic: A Narrative INQUIRY
}

\author{
Agencia en el uso de tecnologías digitales en docentes de inglés en Malasia \\ DURANTE LA PANDEMIA: UNA INVESTIGACIÓN NARRATIVA
}

L'Agentivité PARMi LES ENSEIgNANTS D'ANGLAIS EN MALAISIE À PROPOS De L'UTILISATION DES TECHNOLOGIES NUMÉRIQUES PENDANT LA PANDÉMIE : UNE ENQUÊTE NARRATIVE

\author{
Azlin Zaiti Zainal \\ Senior Lecturer, Faculty of \\ Languages and Linguistics, Universiti \\ Malaya, Kuala Lumpur, Malaysia. \\ azlinzainal@um.edu.my \\ https://orcid. \\ org/0000-0002-0149-9742

\section{Siti Zaidah Zainuddin} \\ Senior Lecturer, Faculty of \\ Languages and Linguistics, Universiti \\ Malaya, Kuala Lumpur, Malaysia. \\ zaidah75@um.edu.my \\ https://orcid. \\ org/0000-0002-3501-9903
}

This research was supported by Universiti Malaya RU Grant Project N. ${ }^{\circ}$ GPFO19A-2020.

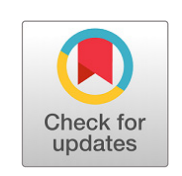

\begin{abstract}
With the closure of schools due to imposed lockdowns in many parts of the world, teachers had to make a rapid transition from teaching in physical classrooms to online teaching, even though they had little to no experience teaching online prior to the pandemic. Adopting a narrative inquiry approach, this study aims to explore the factors that influence Malaysian English language teachers' professional agency in adapting to online teaching. Data were collected via interviews with ten secondary school teachers from rural and urban schools. The findings show how factors such as teachers' perceptions of the affordances of digital tools and existing support structures influence teachers' enactment of agency in online teaching and learning. They also demonstrate teachers' agentic potential to adapt their lessons to suit their learners' needs. These findings suggest the need for teacher professional development programs to recognize teacher agency in the design of future training modules. This involves providing a differentiated training curriculum that can support and sustain language teachers' development organically by taking into consideration their existing technology skills, teaching experiences and work contexts.
\end{abstract}

Keywords: Teacher agency; professional development; ICT; English teachers; narrative inquiry; online teaching.

\section{RESUMEN}

Con el cierre de los establecimientos educativos por causa de las cuarentenas impuestas en muchos lugares del mundo, los docentes se vieron obligados a hacer una transición acelerada de la enseñanza presencial en aulas físicas a la docencia en línea, aun cuando tuvieran poca o nula experiencia con ese tipo de docencia antes

Received: 2021-03-16 / Accepted: 2021-07-26 / Published: 2021-09-11

https://doi.org/10.17533/udea.ikala.v26n3a07

Special issue on The Role of Technology in Language Teaching and Learning amid the Crisis Generated by the COVID-19 Pandemic. Editors: Marta González-Lloret, University of Hawai'i at Mānoa, usa; Laia Canals, Universitat Oberta de Catalunya, Spain; Jorge Pineda, Universidad de Antioquia, Colombia.

(C) 2021 Universidad de Antioquia. This is an open access article distributed under the terms of the Creative Commons License BY-NC-SA 4.0 International. 
de la pandemia. Adoptando un enfoque de investigación narrativa, el presente estudio se propone explorar los factores que influyen en la agencia profesional de los docentes de inglés malayos en su adaptación a la docencia en línea. Se recolectaron datos por medio de entrevistas con diez docentes de educación básica secundaria de escuelas rurales y urbanas. Los resultados muestran cómo factores tales como las percepciones de los docentes sobre las posibilidades de las herramientas digitales y las estructuras de apoyo existentes influyen en el ejercicio de su agencia en la enseñanza y el aprendizaje en línea. También demuestran el potencial agentivo de los docentes para adaptar sus clases a las necesidades de los estudiantes. Estos resultados sugieren la necesidad de crear programas de desarrollo profesional que reconozcan la agencia del docente en el diseño de futuros módulos de formación. Esto implica brindar un currículo de capacitación diferenciado capaz de soportar y sostener de manera orgánica el desarrollo de los docentes de lengua tomando en cuenta sus destrezas tecnológicas previas, sus experiencias en la docencia y los contextos laborales.

Palabras clave: agencia docente; desarrollo profesional; TIC; docentes de inglés; investigación narrativa; enseñanza en línea.

\section{RÉSUMÉ}

Avec la fermeture des établissements d'enseignement en raison des quarantaines imposées dans de nombreuses régions du monde, les enseignants ont été contraints de faire une transition accélérée de l'enseignement présentielle dans des salles de classe à l'enseignement en ligne, même s'ils n'avaient que peu ou nulle expérience dans ce genre d'enseignement avant la pandémie. Adoptant une approche de recherche narrative, la présente étude vise à explorer les facteurs qui influencent l'agence professionnelle des enseignants d'anglais malaisiens dans leur adaptation à l'enseignement en ligne. Les données ont été recueillies au moyen d'entretiens avec dix enseignants d'enseignement secondaire dans des écoles rurales et urbaines. Les résultats montrent comment des facteurs tels que les perceptions des enseignants sur les possibilités des outils numériques et les structures de soutien existantes influencent l'exercice de l'agence des enseignants dans l'enseignement et l'apprentissage en ligne. Ils démontrent également le potentiel agent des enseignants pour adapter leurs cours aux besoins des élèves. Cela suggère la nécessité de créer des programmes de développement professionnel qui reconnaissent l'agence de l'enseignant dans la conception des futurs modules de formation. Cela implique de proposer des programmes de formation différenciée capable de supporter organiquement le développement des enseignants de langues, compte tenu de leurs compétences technologiques antérieures, de leurs expériences dans l'enseignement et de leurs contextes de travail.

Mots clés : agentivité de l'enseignant; développement professionnel; TIC ; enquête narrative; enseignants d'anglais; enseignement en ligne. 


\section{Introduction}

The covid-19 pandemic has impacted the education sector in various ways. With the closure of schools due to imposed lockdowns in many parts of the world, teachers had to make a rapid transition from teaching in physical classrooms to online teaching (Bailey \& Lee, 2020; Kaden, 2020; Trust et al., 2020). A majority of teachers, however, were not prepared to transition to online teaching having had little to no experience teaching online prior to the pandemic (Gudmundsdottir \& Hathaway, 2020). The sudden shift triggered the need for teachers to quickly learn how to use new technologies to teach remotely (Carrillo \& Flores, 2020; Daniel, 2020). Examples of implementation can be seen in an emerging number of studies reporting the use of digital technologies such as video conferencing tools in schools for English language teaching (Cheung, 2021; Singh et al., 2020) and social messaging tools (Budianto \& Arifani, 2021). Although these studies provide us with a better understanding of how language teachers adopted digital tools for online teaching, little is understood about how they exercised their professional agency in using such tools for language teaching.

Teacher agency depends highly on the teacher's individual qualities in terms of professional knowledge and skills (Biesta et al., 2015); and the pandemic has seen teachers across the world attempting to upskill themselves to adjust to the requirements of online teaching, including teachers in English as foreign language context in Malaysia. The Malaysian Ministry of Education introduced various initiatives as part of the national effort towards digitizing education, including most recently Google Classroom as a standard digital platform to be used in all primary and secondary Malaysian schools. However, the adoption of new technologies among Malaysian teachers has been varied due to factors such as lack of access to internet connectivity, lack of facilities, and geographical locations among others (see Zainal \& Zainuddin, 2020). The first Movement
Control Order (MCO) imposed by the Malaysian Government, which had seen nationwide school closures from March 18 until March 31 (and then extended to May 13), has forced teachers to learn to use Google Classroom including the integrated video conferencing tool, Google Meet. To explore these issues, the current study aims to examine Malaysian English language teachers' agency in using digital technologies.

The current study seeks to understand how teachers' professional agency is enacted in their learning of new technologies to deliver instruction from an ecological perspective (Biesta et al., 2015). It also presents an opportunity to closely examine the ways teachers adapt to new modes of working and whether this can be efficiently sustained. Another issue of concern is that this scenario has the potential to aggravate the inequity between certain populations of teachers and learners. For instance, teachers who are from rural schools may find it more difficult than teachers in urban schools to implement information communication technologies (ICT), and this consequently would affect the quality of learners' learning. Arguably, there is a call for "humanizing pedagogies" to online teaching to overcome the issue of inequity (Mehta \& Aguilera, 2020). However, at present it is unclear how teacher agency is enacted in response to the issue of inequity, and through this study, a more cohesive understanding of the structural and cultural conditions that support or constraint teachers' agency in using digital tools during the pandemic can be obtained. The findings of this study will also contribute to our understanding of how teachers perceive the post-pandemic role of technology in teaching and learning.

\section{Theoretical Framework}

With forced closure of schools during the current pandemic, teachers had to adopt new ways of teaching including using digital tools such as videoconferencing technologies to deliver instruction. Related literature to technology used 
in language classroom and teacher agency are reviewed in this section.

\section{Online Teaching and Learning}

With the availability of videoconferencing technologies, such as Zoom, Microsoft Teams, Google Meet, among others, synchronous remote teaching and learning is made possible provided that there is internet connectivity.

Among the advantages that have been highlighted in using the video conferencing technologies is that they provide an increased sense of equity (Carville \& Mitchell, 2000). Educational equity, according to The Organisation for Economic Co-operation and Development OECD (2012), highlights that personal or social circumstances such as gender, ethnic origin, or family background should not be obstacles to achieving full educational potential. The perspective of equality should also cut across learners in the rural and urban areas. However, access to technology especially amongst learners in the rural areas is an obstacle in bridging the gap. Nevertheless, it is noted that educational use of video conferencing has been more established in higher education compared to mainstream schools (see Lawson et al., 2010). The initial uses of videoconferencing technologies in schools tended to be "isolated projects" and were commonly affected by technical problems making it difficult to explore their pedagogical potentials (Lawson et al., 2010, p.303).

The established research literature on video conferencing in the field of computer assisted language learning (CALL), although mainly conducted in the context of higher education, provides some insights into its role in second language learning. Apart from transferring the lecture style of teaching into an online environment, some of these studies have shown that videoconferencing can potentially be used in interactive ways. Wang's (2006) study on university students' learning Chinese using videoconferencing technology has shown that meaningful interaction can be built into online activities where this can lead to negotiation of meaning and language acquisition. Hampel and Stickler (2012) found that the use of video conferencing can promote multimodal communication in language learning. However, to assume that schoolteachers are immediately able to use tools such as video conferencing in interactive ways is rather premature. The pandemic has clearly highlighted the need to further explore the skills and competencies needed for online teaching. As pointed out by Egbert (2020), teachers tend to depend on teacher-directed materials consisting of multiple-choice questions and drillbased activities given that they are not too difficult to put together and require little teacher support.

The existing literature has highlighted different types of skills needed for language teachers to effectively teach online. Hampler and Stickler (2012), for example, proposed a skills pyramid where each skill is built on the mastery of the previous one. They argue that teachers should start with developing basic ICT skills. This is followed by developing specific technical competence for the software, understanding the limitations and the capabilities of the technology, promoting online socialization, promoting communicative competence, applying creativity and choice, and finally, adapting to the teacher's own style.

Although these are clearly important skills that language teachers need to master, they are not without criticisms. Online socialization among learners is important for promoting communication in learning in an online environment; however, Compton (2009) suggests that online socialization through learner-learner interaction should not be viewed as the only method to promote language acquisition. Understanding how to conduct online teaching is therefore clearly important. To address the urban-rural disparities, it is important that teachers are able to apply appropriate remote teaching strategies that consider learners' contexts. In the context of Malaysia, teachers, especially in rural areas, need to consider several context-related factors that influence the appropriacy of technological tools (i.e., the internet connection and the socioeconomic background of the learners). 


\section{Teacher Agency and Professional Development}

Teacher agency can be viewed from the ecological perspective, as proposed by Priestley et al. (2015). While teacher agency was previously viewed as individual teachers' capability to take action (Emirbayer \& Mische, 1998), the ecological model of teacher agency presents agency as being influenced by a configuration of temporal and relational factors. In other words, the model provides insight into how the teachers' experience and environment contribute to their achievement of agency. It is suggested that teachers' achievement of agency may be affected by the following three dimensions: iterational, projective, and practical-evaluative. The iterational dimension entails the role of thoughts and actions accumulated from the past that form patterns that affect present activities. The projective dimension includes aspirations, both short term and long term, that influence one's actions in relation to the possible trajectories of one's future. The practical-evaluative dimension is about the ability of the actor in making decisions based on the alternatives available, considering the cultural, structural, and material factors that surround an actor's present situation. These aspects could also be enabling or constraining factors or resources. The iterational and projective elements may be referred to in one's decision making. This, in turn, allows possibilities for one to not only sustain one's prior practices but also to modify them. Leijen et al. (2020) expanded on the ecological model of teacher agency to demonstrate how teacher agency can be achieved through components such as teachers' professional competence, structural and cultural context, and professional purpose. They also propose that different types of teacher reflections have the potential to strengthen teachers' agency.

Other scholars have highlighted the importance of teachers' working environment. Jenkins (2020) suggested that contextual influences such as school leadership, teacher relationships with others (such as leaders and colleagues), school operational practices, and culture and personal motivation affected teacher agency. Her study found that teachers' agency is manifested as proactively, reactively, and passively depending on the contextual factors. However, adopting a different perspective, Oolbekkink-Marchand et al. (2017) argue that teachers' professional agency is a form of teacher leadership when they actively make use of their professional space. They set forth that teachers "evaluate their agentic space and decide how to act within that space," and they define evaluation of space "as teachers' perceived space and to teachers' achievement of agency as the exploitation of space" (p. 38). Others such as Halvorsen et al. (2019) found that teacher agency is shaped by their perceived professional space.

These recent studies highlight the importance of examining the mediating aspect of professional space and values in studies of teacher agency. This is especially crucial given that teachers' professional space is no longer defined by their physical workplace (the school setting) but rather the digital space in light of the pandemic.

\section{Teacher Agency in the Time of the Pandemic}

Several studies exploring teacher agency during the emergency remote teaching have emerged in recent months. Thumvichit (2021) drew on teachers' responses to a questionnaire and semi-structured interviews to identify teachers' positioning and agentic actions. The results suggest that despite the many constraints that prevented them from exercising other important responsibilities, the teachers maintained their positioning as being professionally responsible for students' learning outcomes. Gudmundsdottir and Hathaway (2020) adopted the PEAT model (Dicte, 2019) in examining teacher agency. They used a survey to analyze teachers' responses according to the following dimensions: Pedagogical, Ethical, Attitudinal and Technical. Their preliminary findings based on data obtained from Norwegian and Us teachers yield some insights into how teachers exercised their agency in the early days of school 
closure. Most of the teachers' reflections were focused on the technical and pedagogical dimensions as opposed to the ethical dimension. Teachers shared their reflections on learning to use new tools and how to teach online but not so much on ethical issues of "privacy, copyright and source criticism when teaching online” (p. 243). Nevertheless, despite having to quickly shift to the online teaching mode, teachers showed positive attitudes.

An implication of Gudmundsdottir and Hathaway (2020) on teacher education is the need for more modelling of online and blended learning environments to prepare teachers for remote teaching. Another implication is for teachers to be exposed to teacher training content that emphasise the affordances of a specific tool in teaching online. Findings of research on the use of videoconferencing in schools also appear to echo this finding. Its use is more likely to be successful when its implementation is coupled with curriculum considerations instead of guided by the technology alone (Smyth \& Fay, 1994). However, in situations where technology is not available, it is important to find out how teachers exercise their agency in ensuring that their students are able to access education remotely.

\section{Method}

The two main questions that drive the study are: (1) What are the factors that influence and constrain their professional agency in adapting to online teaching? and (2) How do Malaysian English language teachers' exercise of professional agency affect their professional development in online teaching?

\section{Participants}

Ten secondary school English teachers from both East and West Malaysia participated in the study on a voluntary basis. All participants were women. With the exception of one teacher who has a degree in Business Admin with a diploma in Education, all teachers have a bachelor's degree in teaching English as a Second Language (TESL). All of the teachers have English language teaching experience ranging from five to 20 years. They teach a mixture of form levels ranging from Form 2 to Form 6 (ages 14-18) students. The researchers contacted the participants and informed them of the particulars of the study, including the purpose of the study, the activities during the interviews as well as the research in general and how much time was required.

\section{Context of the Study}

Four teachers are teaching in rural schools in four different states in Malaysia, and four are in suburban schools in Selangor, Johor, Melaka, and Cyberjaya (See Table 1). All 10 schools are government funded day schools; however, one is a partial day school and another school is under the Trust School Programme, a public-private partnership in education initiated by the Ministry of Education $(\mathrm{MoE})$. It is important to note that the infrastructure for schools under this program is similar to day schools. They, however, are assisted by Leap-Ed Sdn Bhd., a private agency selected by MoE to train and oversee the collaborative teaching and learning in classrooms. Another teacher is currently teaching in one of the schools that was piloted under an initiative introduced by the Malaysian Government in the 1990 s to reform the teaching learning processes in schools to prepare learners for the age of Information Technology (the Smart School Initiative). One teacher (Trisha) is teaching in Miri, a coastal city in north-eastern Sarawak. The main languages are Iban, an indigenous language, and Sarawak Malay, a variety of Standard Malay language. Her students live in longhouses (communal houses built on stilts where several apartments are built under the same roof) and most parents are farmers.

\section{Data Collection}

Data collected consisted of students narratives and interviews.

\section{Narratives}

In the current study, narratives were collected through field texts from two sources, including 
Table 1 Background of Teachers and Context of the Study

\begin{tabular}{|c|c|c|c|c|}
\hline N. ${ }^{\circ}$ & Teacher & Experience & Location of school & Type of School \\
\hline 1 & Azrin & Over 20 years & Klang (Urban) & Day \\
\hline 2 & Trisha & Over 20 years & Miri (Rural) & Day \\
\hline 3 & Salina & Over 20 years & Taiping (Rural) & Day \\
\hline 4 & Ema & Over 20 years & Bandar Melaka (Urban) & Day (Missionary) \\
\hline 5 & Liza & 0 ver 20 years & Cyberjaya (Urban) & $\begin{array}{l}\text { Day (Trust School } \\
\text { Programme) }\end{array}$ \\
\hline 6 & Shahida & Over 20 years & Tangkak (Rural) & Day (Partial Boarding) \\
\hline 7 & Nora & 20 years & Gombak (Urban) & Day (smart school) \\
\hline 8 & Sherry & 20 years & Kuala Langat (Rural) & Day \\
\hline 9 & Afidah & 6 years & Pasir Gudang (Urban) & Day \\
\hline 10 & Alana & 5 years & Pasir Gudang (Urban) & Day \\
\hline
\end{tabular}

individual in-depth interviews. Narrative inquiry helps discover the underlying meaning of the teachers' actions through the story telling of their experiences. This approach is very much rooted in the philosopher and educational theorist John Dewey but was made known by Clandinin and Connelly (2000) as a methodology to describe personal stories of teachers. Narrative inquiry provides the participants a platform to share their views and augment voice through imparting their real-life experiences without having any constraints or fear. To achieve this, the researcher-participant relationship is best to be an active one where researchers need to "continually discuss the participant's stories with the participant and reflect on the personal, social and political background" (Wang \& Geale, 2015, p. 197). Wang and Geale (2015) also highlighted that this approach is not interested primarily in the facts or truth of the accounts given by the participants but rather the underlying meaning. The stories constructed by the participants illuminate the intricacy of the event as well as beliefs that are not articulated verbally but are most often constructed through actions.

\section{Interviews}

After obtaining consent from the participants, ten interviews were conducted online as the Movement Control Order (MCO) period was still in effect.
This prevented any crossing of districts and states to conduct face-to-face interviews. Each interview took between 1 hour 30 minutes and 2 hours according to the most convenient time for the participants. As narrative researchers, we let the participants talk about their experiences without much interruption. The interviews were carried out mainly in English, however, there are some parts of the interaction where the participants were more comfortable using the Malay language, especially when sharing their emotions. The questions in the interview were not limited to the interview prompts which were prepared prior to the session. Throughout the interview sessions, the researchers adhered to the best of their ability to Hollway and Jefferson's (2000) principles of facilitating an interview: the use of open-ended questions, avoiding Why questions because these questions can "encourage intellectualization and can be threatening" and following up by using respondents' ordering and phrasing.

Following Clandinin and Connelly (2000), the study employed three aspects of the narrative approach: Interaction, continuity, and situation. Using this framework, the interviewers analyze the story of the personal experiences of the participants' interactions with other people. In the current study, the interview questions focused more on the Continuity aspect, which involved 
participants' experience in the past, present, and future. Open-ended questions were used, as this method of inquiry is a "way of initiating a research conversation that reflects dynamic and organic dialogical processes" (Etherington \& Bridges, 2011). The researchers began with the participants' teaching background and the background of the school and students. The teachers then shared their experiences in the rest of the interviews. In order for the researchers to prevent any preconceived ideas, meanings were negotiated with the participants. In checking and validating their understanding of the experiences shared by the participants, the researchers continually reconfirmed the stories with the participants.

\section{Data Analysis}

The data was analyzed by both researchers. The interviews were then transcribed and compared with the notes taken by the researchers during the interview. It is important to note that there were some instances where the reviewer used Malay especially in expressing their emotions. The data from both sources were then processed thematically. The study adapted Richard and Morse's (2012) coding approach. They identified three types of coding, which are descriptive, topical, and analytic. Based on the questions asked as well as the context, main ideas are highlighted and categorized into themes.

\section{Findings and Discussion}

The aim of this study was to see how teachers negotiate professionalism through their agency in an online classroom because teacher agency is key to teachers' capacity in enhancing student learning, ongoing professional development, and school improvement (Toom et al., 2015). This section attempts to answer the first research question which is: What are the factors that influence teachers' professional agency in adapting to online teaching?

\section{Teaching Strategies and ICT Use Pre-Pandemic}

Examining the teachers' discourses on their ICT competence prior to the pandemic and the types of formal training they had received related to online teaching provides us with a better understanding of how teachers exercise their agency in response to the requirements of remote teaching. Teachers also acknowledged that the context plays a role in both teachers and students' access to the internet and technology. According to the teachers, their schools were supportive of ICT initiatives even prior to the pandemic. This somehow helped teachers to prepare for online teaching. The schools are generally equipped with infrastructure such as a computer lab and a multimedia room with LCD screen. However, despite the availability of such infrastructure, they did not necessarily use ICT regularly.

Nora, who teaches at an urban school, recalled that the use of ICT in her classroom prior to the MCO was limited to showing videos to her students in a dedicated room in the library, which is equipped with LCD projectors. Her students' use of ICT was mainly for presentation purposes.

Afidah stated that she did not use the ICT lab in her school because teachers had to book it in advance, and there were teachers of other subjects who would also want to use the lab. According to her, although teachers can bring their own LCD projector and laptop to their classes and set them up themselves, this would be a hassle if there are many classes in one day. She said that she would only use ICT once a month prior to the pandemic.

Salina, who teaches at a rural school, noted that the environment of the school is supportive of the government initiatives to promote digital technologies in teaching and learning. Although the school is not considered an urban school, in terms of ICT facilities, the school is well-equipped with an ICT laboratory and the Digital Classroom, a dedicated classroom which has an Internet connection and a television that can be connected to the computer. Despite this, she did not use ICT regularly in her teaching prior to the pandemic. Her use was restricted to showing videos in her teaching, and she would usually bring her own speakers to the classroom. 


\section{Teacher Training on ICT Literacy}

The interviews revealed that teachers' ICT literacy skills can be attributed to formal training and informal training. Formal training is programs initiated by the Ministry of Education or agencies selected by the ministry.

According to Trisha, the training prior to the pandemic included introducing teachers to the use of Google Classroom. Following the training, teachers in her school were encouraged to explore Google Classroom ${ }^{\circledR}$ for teaching. Teachers in her school were already using it but not regularly, and they are already competent in using Google Classroom ${ }^{\circ}$. Although Trisha had used the internet before to search for materials, the move to online teaching was challenging. She stated that "when it comes to online learning, I thought it's quite a big challenge for me... it's like starting from zero."

Similarly, prior to the MCO, Nora did not know how to use video conferencing tools for teaching remotely. Although she attended a training session provided by Pusat Kegiatan Guru (PKG) Gombak on how to use Google Classroom prior to the MCO, it did not prepare her for the use of Google Meet as the training only introduced teachers to the basic functions of Google Classroom. Pusat Kegiatan Guru (PKG) is a unit under the Education Technology Division and is responsible for providing teachers with professional development programs including ICT training. The formal training provided by the PKG Gombak on how to use Google Meet enhanced her skills on using video conferencing tools for teaching. Her online teaching skills were further strengthened by joining many courses and webinars voluntarily, including the ones organized by other PKGs. The teacher demonstrated an enactment of agency by making an active choice to join formal but non-compulsory training, even that offered by PKGs of other districts to upgrade her skills and competencies in online teaching.

\section{Informal Training in ICT Skills}

The teachers' discourses reveal the enactment of their agency in terms of developing themselves professionally are not only by attending formal training on online teaching. Teachers have reported that they learn about how to embed technology into their own online on their own. The importance of social learning and training conditions that contribute to professional agency has been emphasized by Vähäsantanen et al. (2017). Aspects such as peer-learning and community learning are also reported by the teachers.

\section{Self-Learning}

Azrin acknowledged that the development in using technology in the classroom during the emergency online learning is very much an individual initiative. Salina attributed her ability to use Google Meet to teach online as a result of selflearning. As Salina noted, "YouTube actually helps a lot. At the moment we have Google classroom and so on. I learned mostly from YouTube." She learned how to insert video links to Google Forms from watching YouTube videos. Sherry also explained that she learned how to use Google Form, Padlet, Wordwall $^{\circ}$, and LiveWorksheets ${ }^{\circ}$ on her own.

\section{Learning from Peers}

The teachers in this study attributed their learning to the existing support structure in schools in the form of Professional Learning Communities (PLCS) program, introduced by the Malaysian Ministry of Education. The PLC initiative serves as an important platform in promoting teacher competence in ICT use. We note that the teachers participate in knowledge sharing sessions with their peers. It was during the MCO that Salina developed her competence in using Google Classroom . During one of the PLC sessions, she stated that she learned how to use Google Meet ${ }^{\circ}$ to record her lessons. The PLC meetings provided opportunities for her to learn from other teachers such as how to use the social messaging tool, Telegram, to carry out quizzes. Liza also said that she learned how to use new apps for teaching from her colleagues. She explained that that "we found out about a new appthe other day Pair Deck... the teacher then shared 
with the panel". She also said that they would keep on sharing any information about new apps via their department WhatsApp group.

\section{Learning from Communities of Practice}

Apart from learning from colleagues, the teachers also revealed that their learning occurred from joining social media groups that connect them to the community of teachers in Malaysia. Salina stated that she improved her knowledge on how to use ICT for teaching and learning when she joined a Telegram channel, E-didik, an online community in Malaysia that consists of a group of teacher volunteers who offer educational support to teachers throughout Malaysia.

She highlighted the role of discussions amongst colleagues and friends outside the school circle. In the interview data, she commented on how discussions and sharing of information and ideas are regularly done with her friends through social media platforms such as Telegram or WhatsApp. This is a demonstration of the teacher's enactment of her agency in her own professional development. She cited that one of the outcomes of this MCO is that it made her want to learn more on how to build on her newly developed knowledge and skills in using ICT to teach. Joining such an online forum exposes her to a Community of Practice consisting of teachers from all over Malaysia. She says, "the support is not just from our own school but also nationwide."

\section{Teachers' Willingness to Adapt to Online Teaching.}

As agency is a form of achievement, it can be said that the teachers in this study have shown that they are more competent in using ICT tools for online teaching compared to how they were pre-pandemic. With increased competence, the teachers have also demonstrated their willingness to adapt to this new mode of teaching. This willingness to adapt to online teaching enhances their agentic potential in not only learning how to use digital tools for online classroom practice but also in adapting their teaching approach to fit the situation. Being accustomed to teaching in physical classroom settings, the transition to online teaching required them to go beyond their comfort zones and to also tolerate aspects of online teaching that they deemed unsatisfactory. This section will discuss some of these aspects. From the interview data, we found that there is an aspect that is not met when it comes to pedagogy. This is in terms of self-satisfaction. For example, for Azrin, she was not able to replicate what she would normally do in a face-to-face classroom which is to monitor learners' progress. She also stated that she liked to share stories and her experience with learners because she noticed that her students were more engaged in her lesson through sharing of experiences. Technology is a constraint as it prevented her from doing what she would normally do in a physical classroom. She is unable to share that part of herself when conducting online classes. In other words, teacher input is restricted to the delivery of the content of the syllabus.

In addition, while technology has the potential to promote collaborative learning, this process did not happen in her classes. Unlike in a physical classroom where the teacher is able to assign group work in class, the online teaching affected the way she designed her learning activities. For her, online teaching has affected her level of self-satisfaction in how classes are conducted. This is because she is only able to view the product instead of seeing how her efforts have positively impacted her students' understanding and performance.

Another challenge stated by some teachers is the difficulty in getting students' full participation. Salina cited the students' language proficiency as a constraint. A majority of her students do not like written messages when the teacher uses Telegram to communicate. They prefer listening to recorded audio as they could not comprehend written messages. Another factor is the students' geographical location. Students who lived quite far from Taiping town had to go to the town to get internet access. 
These factors affected how Salina enacted her agency in online teaching. Her choice of medium to communicate with her learners was influenced by her perceptions of her learners' needs.

\section{Executing Agency in Online Classroom}

This section will discuss the findings to answer the second research question: How do Malaysian English language teachers' exercise of professional agency affect their professional development in online teaching?

The teachers' discourses on how they conducted online teaching and how they exercised their agency can be viewed from the practical-evaluative dimension of the ecological model of agency (Priestley et al., 2015). We note that their agency was influenced by a host of factors. As suggested by Priestley et al. (2015), an actor's decision-makings are based on a range of alternatives including the cultural, structural, and material factors available in an actor's present situation. In the case of the teachers in this study, the structural guidelines provided by the Ministry of Education, the ICT facilities available, and internet connectivity, the school culture are among the factors that affected their agency.

\section{Teachers' Exercise of Agency in Relation to Structural Conditions}

The guideline given by the Ministry of Education for teachers to conduct their lessons is based on the following categories: online, offline, and onsite. The structural conditions are in place in the form of how often teachers should teach remotely. In terms of implementing lessons remotely, some structure was provided by the school management such as through the reporting of attendance and the problems faced by the teachers. Teachers are allowed to exercise their agency in deciding how best to conduct lessons as long as the teacher follows the timetable. The timetable given provided a form of structure for teachers to implement online lessons. For online teaching, Azrin used Google Meet to conduct online lessons for her class. Two classes were combined in one online lesson. Social messaging tools such as WhatsApp ${ }^{\oplus}$ and Telegram ${ }^{\circ}$ were the most commonly used tools to communicate with learners.

Even though Azrin indicated that there was less sense of personal achievement in terms of her students' understanding of her lesson, online teaching has increased her confidence in using technology. She learned to use quizzes in her teaching, but she did not attempt to use other types of ICT applications and prefers to use what she is comfortable with to ensure one hour of smooth delivery of online lessons. The teacher is agentic in the sense that she is able to carry out the lesson using the tools she is comfortable with.

\section{Adapting Lessons Based on the Understanding of Context}

Access to technology amongst students is one of the factors that influence teachers' agency in language classrooms. A common view in the teachers' narratives is that context or location is a determiner of the technology used by students. Taylor (1991) stated that agency is interconnected with responsibility and self-evaluation, where a person is not only governed by his or her sense of duty but is also responsible in their evaluations when making decisions.

\section{Using Social Media to Deliver Lessons and Conduct Assessments}

Although teachers were already competent in using Google Meet $^{\circledR}$ as a video conferencing tool to carry out synchronous lessons, it was not feasible for them to use it all the time. Students' lack of internet access or unstable internet connection and lack of access to devices were among the factors affecting the teachers' use of Google Meet ${ }^{\circ}$. This was a more common scenario for teachers teaching at rural schools. Nevertheless, it was observed that these teachers were able to take an agentive role despite these constraints by using social media. For example, for Sherry, because a majority of the students were unable to attend 
synchronous sessions via Google Meet ${ }^{\oplus}$, she used social media such as Telegram ${ }^{\oplus}$ and WhatsApp ${ }^{\oplus}$ to conduct lessons with the students.

Shahida noted that the range of online activities she can implement are limited because the internet connection can be slow for her learners. This made her resort to using applications that do not require strong internet connection like Kahoot ${ }^{\circ}$. She also prefers to use Telegram, a social media application to conduct her lessons as she could not get full participation if she were to use Google Meet ${ }^{\circ}$ all the time. The use of Google Meet ${ }^{\circledR}$ would be heavy for her students' internet data and students from low socioeconomic backgrounds. For her, Telegram ${ }^{\circledR}$ is convenient and flexible. She further explained,

Considering where my students come from, the nature of the internet, so most of my classes are actually on Telegram. And I see that Telegram can be very convenient. You can have voice chat. So, I can actually talk to my students, have a discussion. There's also the video and quiz. I can ask my students to record and send their presentations.

From their narratives, the teachers also indicated an awareness of how assessments can be done using Telegram. They would use the quiz feature of Telegram or post links to Google Forms containing reading or listening comprehension questions. They would also use voice chats to assess students' speaking skills.

\section{Using Technology to Support Learners' Learning}

Another aspect of teacher agency that was noticeable from the interview data was teachers' awareness of how online teaching can be utilized to enhance certain aspects of language teaching and learning. Although the teachers had to change their teaching methods from what they were used to doing in physical classrooms, they also reported how the use of an online mode of teaching has its advantages. For example, Nora had to adapt her teaching methods when teaching online. She did not assign group work to her learners. Although her teaching approach was not student-centered (unlike when she teaches in a physical classroom), the use of Google Forms to assign her students work allowed her to focus on areas that her students needed to improve on. Google Forms provided the tools to analyze student responses to plan individualized interventions.

For Liza, although the school where she teaches is located in an urban area, the students who attend the school are from different socioeconomic backgrounds, ranging from middle-income to low-income groups. In physical classrooms, some students may be shy and may not necessarily speak much. However, during online lessons she discovered that some students appeared to be more active in lessons. She stated that "introverts are more comfortable during speaking practice; they would give feedback they feel more confident and comfortable."

\section{The Role of the School Culture \\ in Supporting Teacher Agency}

As suggested by Edwards (2015), there is a significant link between teachers' agency and prominent issues such as social justice, professional isolation, and teacher autonomy. These issues are even more prominent in the context of the pandemic. In the context of this study, the school culture is critical in addressing the issue of social disparity, that is the disparity between students with access and students without access to technological tools. For Shahida, the school administrative officers played a role in ensuring that disadvantaged students were not left behind. Students from a low socioeconomic background who did not have access to a digital device and internet connectivity were identified. Her school worked closely with PIBG or the Parent Teachers Association to provide the necessary devices and internet data for these students. Without such intervention from the school, the teacher would not have been able to exercise her agency in carrying out online lessons.

According to Shahida, the community of teachers in her schools also played a role in ensuring 
that they were able to address any issues that arose during online teaching. This is also a reflection of collective teacher autonomy as they gathered together to discuss ways to assist problematic students. These issues may not only be about the teaching pedagogy but also other matters related to student attendance and identifying students who needed more help.

For Sherry, live video conferencing with her students was impossible to conduct as a majority of students in her class did not have internet access. Online lessons were not feasible for these students. However, her school had developed action plans to address this issue by ensuring that learning modules were disseminated to these disadvantaged students. The school helped with printing hard copies of these modules and delivered them to the individual students.

\section{Teachers' Post-Pandemic Perceptions of the Role of Technology}

Teacher agency can also be viewed from the projective dimension and how their aspirations are linked to future trajectories (Priestley et al., 2015). In the context of the current study, this is related to how the teachers perceived the role of their professional competence in ICT for future application. The teachers in this study have demonstrated an increase in their knowledge and skills in online teaching during the $\mathrm{MCO}$ as an outcome of their agentic action in pursuing new skills via self-learning, peer learning and by joining an online community of teachers. The teachers in the study have also shown agency in their classroom practices despite the structural and socio-cultural conditions. However, with the opening of schools, the requirement to teach remotely has diminished. There is no longer a need to use videoconferencing technology to deliver instruction when physical classes resume. Having developed professionally in using ICT tools as an emergency response to the pandemic, the question of continuity in their professional development remains.
In the context of school reform, teachers are expected to continue to develop professionally to achieve reform goals. However, the pandemic crisis is not similar to a school reform scenario. The crisis has disrupted existing classroom teaching norms and accelerated change in teachers' practice in ways that were not possible in a typical school reform effort, which can be met with resistance. Teachers' narratives on how they envision the post-pandemic role of technology is also key to understanding their agency in continuing to develop professionally.

Salina, for instance, changed her attitudes towards digital technology. Prior to the MCO, she did not see the importance of learning technologies such as Google Classroom. Having been forced to learn to use it, adopting the technology in her teaching and being able to experience the usefulness of the technology made her want to learn more about how to use technology for teaching. She is still interested in learning how to use technology when school reopens (e.g., designing your own board games). However, the teacher perceives the role of technology as supplementary to face-toface teaching. For her, technology can be used "to give extra work during the weekend."

The peripheral role afforded to post-pandemic digital technologies, however, is not necessarily an indication that their classroom practice will be the same as before the pandemic. Their practice may evolve in new ways post-pandemic as teachers adapt their face-to-face teaching to incorporate digital technologies.

\section{Conclusion}

The COviD-19 crisis arguably serves as a strong force that pushes a great majority of teachers to use their agency in online teaching, a feat that no previous ICT in education policy was able to accomplish. The unprecedented scenario has disrupted the existing classroom teaching practices of language teachers, forcing them to migrate to online platforms. In the wake of the pandemic, 
teachers had to learn not only how to use new digital tools but also to take into consideration the socio-cultural conditions in implementing online lessons. As shown by the study findings, the teachers needed to evaluate their own existing ICT literacy and seek ways to increase their competence in order to conduct their lessons online. To this end, they resorted to seeking support from their peers and online communities and also had to be prepared to learn how to use the relevant tools on their own. The existing school support structure serves as an enabler for teachers to collaborate with each other and to collectively improve professionally. Clearly, having such structural support is an essential element in promoting teachers' agentic potential and reflects the ecological perspective of agency.

Teacher agency, as the capacity to take action, was also demonstrated in their online classroom practices. Transferring their pedagogical content knowledge to their online space is not straightforward as they also had to adjust their teaching methods to accommodate the constraints of online teaching. The teachers depended much on their agency in order to navigate the online teaching space and ensure that their students were able to participate in lessons. Teachers' expectation especially in replicating teacher-student relationships when conducting their online classroom was often not met when compared with the physical classroom. These teachers were accustomed to applying student-centered teaching approaches in physical classrooms. The shift to online teaching, especially when they had to use video conferencing tools, required them to reconsider their classroom activities. The affordances of the tool, the students' ability to access, and the external support received from their school all play a role in their manifestation of agency.

Nevertheless, these teachers' exercise of agency also had its limitations. The rural-urban disparity affected the ways the teachers implemented their lessons. The study revealed that the location of the students, especially those who lived in the rural areas, were largely affected by the lack of a stable internet connection. Without an Internet connection and appropriate digital devices, these students could not participate in online lessons. They missed out on aspects such as teacher-student interaction and peer-peer interaction which are essential for language learning. An implication of this is that teachers would need to recognize that their teaching approaches would not only involve adaptation during periods of lockdown but also adaptation when the school reopens to address these students' needs.

This study explored the factors that contributed to language teachers' agency and how their agency was manifested into their professional development in online teaching. All the teachers have indicated that they now have more knowledge on how to teach online compared to before the pandemic through formal training, self-learning, and learning from peers and community. One thing we note from this study is that their peer-learning, although intentional, is situation-specific. Teachers reported that they learned about new apps and how to use digital tools from their peers as and when the need arose, which reflects the organic nature of teachers' professional development. A limitation of this study is that we did not look closely at how these teachers exercised their agency in teaching and testing particular language skills online and to what extent these actually reflected professional competence in online language teaching. Further research into how teachers utilized ICT in teaching and testing specific skills online would be welcomed to understand how teachers' articulation of their ICT skills is related to their professional development. This would help training providers to plan the types of courses teachers need according to different needs and trajectories in the future. Future research may also include an exploration of teachers' post-pandemic classroom practices, especially how teachers provided differentiation to their students. 


\section{References}

Aguliera, E., \& Nightengale-Lee, B. (2020). Emergency remote teaching across urban and rural contexts: perspectives on educational equity. Information and Learning Sciences, 121(5/6), 471-478. https://doi. org/10.1108/ILS-04-2020-0100

Anderson, T., Liam, R., Garrison, D. R., \& Archer, W. (2001). Assessing teaching presence in a computer conferencing context. Journal of Asynchronous Learning Networks, JALN, 5 (20), 1-17.

Bailey, D. R., \& Lee, A. R. (2020). Learning from experience in the midst of COVID-19: benefits, challenges, and strategies in online teaching. Computer-Assisted Language Learning Electronic Journal, 21(2), 178-198.

Biesta, G., Priestley, M., \& Robinson, S. (2015). The role of beliefs in teacher agency. Teachers and teaching, 21(6), 624-640. https://doi.org/10.1080/135406 02.2015 .1044325

Budianto, Langgeng, and Yudhi Arifani. (2021). Utilizing WhatsApp-driven learning during Covid-19 outbreak: EFL users' perceptions and practices. Computer-Assisted Language Learning, 22(1), 264-281.

Butler, M., \& Fawkes, S. (1999). Videoconferencing for language learners. Language Learning Journal, 19(1), 46-49. https://doi. org/10.1080/09571739985200091

Carrillo, C., \& Flores, M. A. (2020). covid-19 and teacher education: a literature review of online teaching and learning practices. European Journal of Teacher Education, 43(4), 466-487. https://doi.org/10.1080/0 2619768.2020.1821184

Carville, S., \& Mitchell, D. R. (2000). 'It's a bit like Star Trek': The effectiveness of video conferencing. Innovations in education and training international, 37(1), 4249. https://doi.org/10.1080/135580000362070

Cheung, A. (2021). Language teaching during a pandemic: A case study of zoom use by a secondary ESL teacher in Hong Kong. RELC Journal, 0033688220981784. https://doi.org/10.1177/0033688220981784

Clandinin, D. J., \& Connelly, F. M. (2000). Narrative inquiry. Experience and story in qualitative research. Jossey Bass.

Compton, L. K. (2009). Preparing language teachers to teach language online: A look at skills, roles, and responsibilities. Computer Assisted Language Learning, 22(1), 73-99. https://doi. org/10.1080/09588220802613831
Daniel, J. (2020). Education and the COVID-19 pandemic. Prospects, 49(1), 91-96. https://doi.org/10.1007/ s11125-020-09464-3

Dicte (2019). Pedagogical, ethical, attitudinal and technical dimensions of digital competence in teacher education. Developing ICT in Teacher Education Erasmus+project. https://dicte.oslomet.no/dicte/

Edwards, A. (2015). Recognising and realising teachers' professional agency. Teachers and Teaching, 21(6), 779-784.

Egbert, J. (2020). The new normal?: A pandemic of task engagement in language learning. Foreign language annals, 53(2), 314-319.

Etherington, K., \& Bridges, N. (2011). Narrative case study research: On endings and six session reviews. Counselling and Psychotherapy Research, 11(1), 11-22. https://doi.org/10.1080/14733145.2011.546072

Emirbayer, M., \& Mische, A. (1998). What is agency? American Journal of Sociology, 103(4), 962-1023. https://doi.org/10.1086/231294

Garrison, D. R., Anderson, T., \& Archer, W. (2003). A theory of critical inquiry in online distance education. Handbook of distance education, 1, 113-127.

Gudmundsdottir, G. B., \& Hathaway, D. M. (2020). “We always make it work": Teachers' agency in the time of crisis. Journal of Technology and Teacher Education, 28(2), 239-250.

Hollway, W. \& Jefferson, T. (2000) Doing qualitative research differently. Sage Publications. https://doi. org/10.4135/9781849209007

Halvorsen, Ø. W., Eide, L., \& Ulvik, M. (2019). Extension and remodelling of teachers' perceived professional space. Teachers and Teaching, 25(8), 1030-1042. https://doi.org/10.1080/13540602.2019.1702519

Hampel, R., \& Stickler, U. (2012). The use of videoconferencing to support multimodal interaction in an online language classroom. ReCALL, 24(2), 116-137. https://doi.org/10.1017/S095834401200002X

Hodges, C., Moore, S., Lockee, B., Trust, T., \& Bond, A. (2020). The difference between emergency remote teaching and online learning. Educause review, 27, $1-12$.

Husu, J. (2000). Supporting remote communities with a shared virtual classroom: A view of social contexts. Journal of Information Techology for Teacher Education, 9(2), 255-268. https://doi. org/10.1080/14759390000200085 
Imants, J., \& Van der Wal, M. M. (2020). A model of teacher agency in professional development and school reform. Journal of Curriculum Studies, 52(1), 1-14. https://doi.org/10.1080/00220272.2019.1604809

Jenkins, G. (2020). Teacher agency: The effects of active and passive responses to curriculum change. The Australian Educational Researcher, 47(1), 167-181. https://doi.org/10.1007/s13384-019-00334-2

Kaden, U. (2020). covid-19 school closure-related changes to the professional life of a K-12 teacher. Education Sciences, 10(6), 165. https://doi.org/10.3390/ educsci10060165

Lawson, T., Comber, C., Gage, J., \& Cullum-Hanshaw, A. (2010). Images of the future for education? Videoconferencing: A literature review. Technology, Pedagogy and Education, 19(3), 295-314. https:// doi.org/10.1080/1475939X.2010.513761

Leijen, Ä., Pedaste, M., \& Lepp, L. (2020). Teacher agency following the ecological model: How it is achieved and how it could be strengthened by different types of reflection. British Journal of Educational Studies, 68(3), 295-310. https://doi.org/10.1080/0007100 5.2019 .1672855

Mehta, R., \& Aguilera, E. (2020). A critical approach to humanizing pedagogies in online teaching and learning. The International Journal of Information and Learning Technology, 37(3), 109-120. https:// doi.org/10.1108/IJILT-10-2019-0099

Oolbekkink-Marchand, H. W., Hadar, L. L., Smith, K., Helleve, I., \& Ulvik, M. (2017). Teachers' perceived professional space and their agency. Teaching and Teacher Education, 62, 37-46. https://doi. org/10.1016/j.tate.2016.11.005

Priestley, M., Biesta, G., \& Robinson, S. (2015). Teacher agency: What is it and why does it matter? In J. Evers \& R. Kneyber (Eds.), Flip the system (pp. 134-148). Routledge. https://doi. org/10.4324/9781315678573

Richards, L., \& Morse, J. M. (2013). Readme first for a user's guide to qualitative methods. Sage.
Singh, C. K. S., Singh, T. S. M., Abdullah, N. Y., Moneyam, S., Ismail, M. R., Tek, O. E., ... \& Singh, J. K. S. (2020). Rethinking English language teaching through Telegram, Whatsapp, Google Classroom and Zoom. Sys Rev Pharm, 11(11), 45-54.

Smyth, W., \& Fay, J. (1994). Video conferencing between schools in Northern Ireland and schools in France. North Eastern Education and Library Board.

Taylor, C. (1991). The ethics of authenticity. Harvard University Press.

Thumvichit, A. (2021). English language teaching in times of crisis: Teacher agency in response to the pandemic-forced online education. Teaching English with Technology, 21(2), 14-37.

Toom, A., Pyhältö, K., \& Rust, F. O. C. (2015). Teachers' professional agency in contradictory times. Teachers and Teaching, 21(6), 615-623. https://doi.org/10.1080 /13540602.2015.1044334

Trust, T., Carpenter, J. P., Krutka, D. G., \& Kimmons, R. (2020). \#RemoteTeaching \& \#RemoteLearning: Educator tweeting during the COVID-19 pandemic. Journal of Technology and Teacher Education, 28(2), 151-159. https://www.learntechlib.org/ primary/p/216094/

Vähäsantanen, K., Paloniemi, S., Hökkä, P., \& Eteläpelto, A. (2017). Agentic perspective on fostering workrelated learning. Studies in Continuing Education, 39(3), 251-267. https://doi.org/10.1080/015803 7X.2017.1310097

Wang, C. C., \& Geale, S. K. (2015). The power of story: Narrative inquiry as a methodology in nursing research. International journal of nursing sciences, 2(2), 195198. https://doi.org/10.1016/j.ijnss.2015.04.014

Wang, Y. (2006). Negotiation of meaning in desktop videoconferencing-supported distance language learning. ReCALL, 18(1), 122-145.

Zainal, A. Z., \& Zainuddin, S. Z. (2020). Technology adoption in Malaysian schools: An analysis of national ICT in education policy initiatives. Digital Education Review (37), 172-194.

How to cite this article: Zainal, A. Z., \& Zainuddin, S. Z. (2021). Malaysian English language teachers' agency in using digital technologies during the pandemic: A narrative inquiry. Íkala, Revista de Lenguaje y Cultura, 26(3), 587-602. https://doi.org/10.17533/udea.ikala.v26n3a07 